\title{
A nyelvi variativitás elméleti kérdései
}

\section{Bevezetés}

Tanulmányunkban a nyelvi variativitás kérdéskörével foglalkozunk. A tárgyalt nyelvi jelenség részletes elemzése azért fontos és indokolt, mert bár ismert a nyelvészek körében, ám mind a magyarországi, mind pedig a nemzetközi szakirodalomban elsősorban a nyelvi változékonyság (nyelvi variabilitás) kérdéskörén belül többnyire szociolingvisztikai elméleti keretben vizsgálják, kivételt ez alól az orosz szakirodalom képez. A szakemberek többsége, ha foglalkozik is a variativitás kérdéskörével, más jelentésben alkalmazza a hozzákapcsolódó szakterminológiát, a terminológiai többértelmüség következtében pedig egyes esetekben átfedések vannak a variativitás és a vele szoros kapcsolatban álló lexikológiai jelentésviszonyok és más nyelvi jelenségek között. Ennek oka a kérdés más szempontú megközelítése, ezért munkánkban több variativitással kapcsolatos és tőle elhatárolandó fogalmat, nyelvi jelenséget is érintünk.

\section{Nyelvi szimmetria és aszimmetria}

A nyelvi variativitás témakörének leírását a szimmetria/aszimmetria dichotómia értelmezésével célszerü kezdeni. A szimmetria és aszimmetria olyan univerzálék, amelyek minden dinamikus rendszerre, így a nyelvi rendszerre is érvényesek.

A szimmetria az állandóság és az egyensúly megnyilvánulása a világ elemeinek együttlétezésében és kölcsönhatásában. Legfőbb jellemzői: a törvényszerűség, a rendszerszerü elemek közötti viszonyok megőrzése és az invariativitás. Az aszimmetriában az egészet alkotó rendszer részei közötti egyensúly ingadozása fejeződik ki (vö. Gak 1990, 1998).

A nyelvi szimmetria/aszimmetria dichotómiára már a görög sztoikusok is rámutattak, de tudományos igénnyel először Saussure és tanítványai, Bally és Karcevski foglalkoztak vele. Bally nyelvi szabályszerüségként írta le a kifejezendő tartalom és a nyelvi kifejezések közötti aszimmetriát (vö. Bally 1955; Harina 2008; Oszetrov 2009). Karcevski a nyelvi jel dualizmusáról szólva a szabályszerüséget hangsúlyozza: „A jelölő (hangzás, hangtest) és a jelölt (a funkció) folyamatosan elcsúszik a valóság lejtőjén [...] Ezek aszimmetrikusak: párban lévén (accouples) a bizonytalan egyensúly állapotában vannak. A jelek rendszere ezen aszimmetrikus dualizmusának köszönhetően tud fejlődni a nyelvi rendszer: a jel »adekvát« pozíciója folyamatosan áthelyeződik (a jeleknek) a konkrét szituációhoz való alkalmazkodása következtében" (Karcevski 1965: 93; ford. Lörincz J.).

Karcevski elsősorban a paradigmatikus tengelyen meglévő szimmetria/aszimmetria dichotómia leírásával foglalkozott a variativitás két típusában: 
1. A variativitás a nyelvi szimmetriától való eltérés. A variativitás megjelenési formái változatlan jelölt esetében: allomorfia, beleértve a határeseteit is, valamint a szinonímiát és a szuppletivizmust, azaz a különböző tőből képzett egyazon kategóriakifejező jelölőket, mint például a magyarban a sok-több, az oroszban а плохой-хуже 'rossz, rosszabb'; valamint a homoszémiát. Meg kell jegyeznünk, hogy ez a felfogás nem tér ki a variativitás mint felettes fogalom alá sorolt különböző jelenségek közötti eltérésekre, így egy szintre kerülnek különböző, alaki és jelentés tekintetében is lényeges eltérést mutató nyelvi jelenségek, mint például a homoszémia, valamint a szinonímia is.

2. A variativitás megjelenési formái változatlan jelölő esetében: poliszémia, beleértve a határesetét, a homonímiát is (Karcevski 1965: 85-90; Harina 2008; vö. még Pete 2004). Ebben a rendszerben az alapvető problémát az okozza, hogy Karcevski a varitivitás fogalmát igen tágan értelmezve a poliszémiát és a homonímiát is a variativitás körébe vonja, nem téve különbséget a különböző szemantikai jelentésviszonyok között.

Gak (1998: 47) a nyelvi jel aszimmetriájának jóval tágabb vizsgálati körét javasolja, amelyben az aszimmetria nem korlátozódik a paradigmatikus tengelyre, hanem kiterjed a szintagmatikus tengelyre is.

1. Az aszimmetria a szintagmatikus tengelyen a következő nyelvi jelenségeket foglalja magába:

a) egy tartalmi egység két vagy több formai egységgel kifejezve: analitikus szerkezet, kifejtett jelölés, frazeológiai egység;

b) két vagy több tartalmi egység kifejezése egy formai egységgel: kondenzáció, tömörített jelölés, jelöléskeveredés, kumuláció.

2. Szemiotikai területen a következö jelenségek tartoznak az aszimmetria körébe:

a) a várt formai jelölö hiánya meghatározott tartalmi egység kifejezésére: egyszerüsített jelölés, zéró morféma, ellipszis, elhallgatás;

b) a várt tartalmi egység hiánya megfelelő formai egység megléte esetén: deszemantizáció, tartamilag üres jelek használata, szemiotikai jeltöbblet.

Meg kell jegyeznünk, hogy Gak a tartalmi egységet a jelentés szinonimájaként értelmezi. A szerző a következő aszimmetriajelenségekkel foglalkozik (vö. Gak 1998: 47):

1. Rendszerszintü aszimmetria. Például: a személytelen igék ragozása nem teljes paradigmában jelenik meg.

2. Szerkezeti aszimmetria. Például: a mondat szerkezete és jelentése között.

3. Funkcionális aszimmetria. Az adott nyelvi elem mit jelent és milyen funkciót tölt be a közlésben.

4. Dinamikus aszimmetria. Ez utóbbi a nyelvi elemek fejlődésének egyenlötlenségét vizsgálja a nyelv történeti fejlődési folyamatában egy nyelven belül, illetve a rokon nyelvekben. 


\section{A nyelvi változás}

Minden nyelv alapvető tulajdonsága a változékonyság. Ha elfogadjuk, hogy a struktúra a nyelv szíve, akkor a változás a lelkének tekintendő (vö. Wolfram 2006). Már Darwin evolúcióelmélete is számot ad arról, hogy a természetben folyamatos változások mennek végbe. Ez a változás a nyelvben is megfigyelhető, a rendszer szintjén azonban lassú folyamat, és az írott szövegekben nem mindig érződik (vö. Nádasdy 2003: 3). Ennek ellentmondani látszanak az internetes közösségi oldalak szövegeiben megfigyelhető grammatikai és lexikai változások (Istók 2019).

A nyelvi változás mibenlétével kapcsolatban két lényeges nézőpont alakult ki. Az első szerint csak a strukturális következményekkel járó változás tekinthető változásnak (vö. Wardhaugh 2002: 169), ugyanis a nyelvi változás mindig szabályszerü és rendszerszerü. Szabályszerü, mert a nyelvi rendszert szabályok müködtetik, rendszerszerü, mert a változás a nyelvi rendszer egészét érinti. A rendszer egészét nem érintő folyamatok nem tekinthetők nyelvi változásoknak (vö. Nádasdy 2003). Ezen meghatározás alapján a szókincsbeli változások nem minösülnek nyelvi változásnak.

A másik - történeti szempontú - megközelítés szerint azonban a szókincs változásait is a nyelvi változások körébe kell sorolni: a nyelvi rendszernek vannak olyan azonos típusú elemeket tartalmazó részrendszerei, amelyek ellenállóbbak a változásokkal szemben, a lexémarendszer azonban a változások szempontjából nyitottabb jellegü, ami lazább strukturáltságának és sokirányú rendszerkapcsolatainak köszönhetö (vö. Benkő 1988: 86-8).

A nyelvi változásnak különböző okai lehetnek: „A nyelvi változást lehetővé és szükségessé a belső nyelvi és a nyelvhasználati variáció, illetőleg a változatok és variánsok közötti beszélöi választások teszik, mely utóbbiakat biológiai, lélektani és társadalmi tényezők irányítják. Ezért a nyelvi változások vizsgálata szempontjából a nyelvhasználati változatosságnak és a beszélői választások variálódásának a vizsgálata kitüntetett fontosságú” (Kiss 2008: 260). Azaz: „vannak a nyelvi változásnak olyan területei, jelenségei, amelyek nyelvrendszertani okokkal magyarázhatók (például a hangváltozások egy része), $\mathrm{s}$ vannak olyanok, amelyek társadalmiakkal (a szókincs bővülése, szavak kiveszése például)" (Kiss-Pusztai 2003: 26). Ennek értelmében szokás a nyelvi változás külső (nem természetes) és belső (természetes) okairól beszélni (vö. Sándor 2001; Wardhaugh 2002: 169-70). Ez a terminológiai kettősség azonban nem szerencsés, mert egyrészt nehéz eldönteni, hogy mi is számít valójában külsőnek és mi belsőnek, másrészt pedig azért, mert a külső és a belső okok elválaszthatatlanok egymástól, azaz a nyelvi elemek kettős beágyazottságúak. Az sem elhanyagolható kérdés, hogy külső okokon a társadalmi hatásokat vagy a más nyelvek, nyelvváltozatok hatásait értjük-e (vö. Bynon 1977: 108-67, 198213; McMahon 1994; Romaine 1995).

A nyelvi változások közvetlen következménye, hogy a nyelvben egy adott idöszakban egyszerre élnek a régi és az új jelenségek. „Mindennemü nyelvi változás, minden előzmény-következmény viszony egy időben, legalábbis a változás lezajlásának a kronológiai határain belül variációkkal jár együtt: az előzmény és a következmény szinkrón szembenállását, együttélését feltételezi” (Benkő 1988: 63-4). 
A nyelv változásának tehát természetes velejárói a nyelvi rendszerben folyamatosan végbemenő konvergens és divergens mozgások (vö. Horváth 2004). Ezeknek köszönhetően jön létre a nyelvi variativitás, más kifejezéssel a nyelvi variancia, amelyeket a szakirodalomban egyes szerzők egymás szinonimájaként alkalmaznak.

\section{Nyelvi variativitás}

A nyelvi jelenségek variáns-invariáns korreláció szerinti tudományos megközelítése a Prágai Nyelvészkör fonológiai kutatásaival indult el, majd ennek alapján a kutatások kiterjedtek a többi nyelvi szinten lévő elemek vizsgálatára is. A Prágai Nyelvészkör kutatásainak részletes ismertetését a hazai nyelvészeti szakirodalomban elsőként Péter Mihály (1980) tette közzé.

A Prágai Nyelvészkör vizsgálatai a fonológiában rövid időn belül eredményeket hoztak, a magasabb nyelvi szintek variánsainak leírásával kapcsolatos kutatások azonban nem jártak egyértelmü sikerrel: az alapfogalmak még ma sem eléggé tisztázottak, emellett pedig sok a terminológiai többértelmüség. Ezért a variativitás leírására szüknek bizonyult minden korábban ismert nyelvészeti diszciplína.

A Prágai Nyelvészkört követően a variativitás kutatásában a stratifikációs grammatika jelentett előrelépést. A stratifikációs grammatika (vö. latin stratum 'lépcső, szint') a nyelvi rétegek kölcsönhatását írja le két végpont között. A két végpontot a „hiperszemémikus” és a „hiperfonémikus” rendszerek alkotják, amelyek között több szint létezik, az egyes szintek pedig átjárhatóak (vö. Máté 1998: 111). E tudományágon belül az első alapvetést a variánsok nyelvi funkciójával kapcsolatban a strukturalista nyelvészeti kutatásokat folytató Lamb (1962) munkájában találjuk. Lamb a nyelvi rendszer olyan modelljét igyekszik felépíteni, amelyben az egyes nyelvi egységek közötti szemantikai viszonyok játsszák a legfontosabb szerepet. Mivel az elemi nyelvi egységek és viszonyok különbözőképpen kombinálódnak, a különböző nyelvi viszonyok leírásában a legfontosabb funkciót az egyes szemantikai egységek közötti kapcsolatok jelentik. Ebben nem nehéz felismerni a funkcionális szemantikaimezö-elmélet (vö. Bondarko 1990), valamint a későbbi kognitív nyelvelmélet alapjait (vö. Langacker 1987; Tolcsvai Nagy 2004). Szintén itt kell megemlítenünk Lockwood egyik munkáját (1972), amelyben a nyelvi variánsok elméleti kérdéseivel is foglalkozik.

A variativitás kutatásában előrehaladást jelentett W. Klein Variantengrammatik címü tanulmánya (1974), amely egy elméleti megalapozottságú szociolingvisztikai hátterü variációs grammatika létrejöttét jelzi. Klein kutatásaiban különböző nyelvi területeket vizsgált, és a változatok bemutatásakor makroszociális, szituatív, időbeli, térbeli paramétereket is figyelembe vett. A szerző azokat a fonológiai, morfológiai és szintaktikai szabályokat írta le, amelyek a variánsok létrejöttéhez vezethetnek. A variációs grammatika Hymes azon elméletét veszi alapul, amely szerint a beszélő nyelvi kommunikációs kompetenciája heterogén, a különböző változatokat különböző módon birtokolja és alkalmazza (vö. Hymes 1975).

A variációs grammatika kizárólag a standard német nyelvváltozatokat vizsgálja, a különböző német nyelvterületeken a különböző „,nagyrégiók”, úgynevezett areák 
alapján elkülöníthető legnagyobb presztízsű változatokat. Ezek a nyelvjárási régióknál nagyobb területekre kiterjedő változatok. A variációs grammatika a lexikai variativitás mellett grammatikai kérdésekkel is foglalkozik: például szóalkotásmódok, szórend, a mondatrészek sorrendje a mondatban stb. Az irányzat hangsúlyozza, hogy nem érdemes nemzeti (országonkénti) változatokról beszélni, hiszen egy nyelvi elem vagy forma használata szinte sohasem esik egybe az országhatárokkal (a témával kapcsolatban az alábbi internetes oldal nyújt átfogó képet: W1 = http:// mediawiki.ids-mannheim.de/VarGra/index.php/Start).

A variációs grammatika mellett a variációs nyelvészet (Varietätenlinguistik) müszó használatával is folyamatosan találkozunk a német szakirodalomban, amely azonban továbbra is a szociolingvisztikai módszerü vizsgálatokat fedi le (vö. Sinner 2014; Elspaß-Dürscheid-Ziegler 2017; Dürscheid-Schneider 2019). Ezt támasztja alá, hogy a Varietätenlinguistik a Soziolinguistik szinonimájaként is megjelenik a szakmunkákban.

A nyelvi variánsok létrejöttének és müködési módjuknak a leírásában a szociolingvisztikai kutatások sokáig meghatározóak voltak. A szekuláris nyelvészet - amelyet neveznek kvantitatív, valamint korrelációs szociolingvisztikának is, a magyar nyelvészeti szakirodalomban pedig élönyelvi vizsgálatnak - a nyelvi változásokat kutatva a különböző nyelvi változók (köztük a variánsok) müködési szabályait, használati kötöttségeit írja le (vö. Trudgill 1997: 72, 74, 88, 89).

A kérdés terminológiai sokszínüségét jelzi, hogy a nyelvi variativitás leírását többnyire két, egymástól eléggé távol álló tudományág, a szociolingvisztika és a kognitív nyelvészet keretein belül találjuk meg mind a nemzetközi, mind pedig a magyar szakirodalomban. „A szociolingvisztika alaptétele szerint nincsen homogén beszélőközösség és nincsen egystílusú beszélö (Labov 1982), legalábbis a mai európai típusú kultúrákban. A nyelvi variancia ekkor az anyanyelvváltozat (vernakuláris) és az egyéb változatok közötti viszonyok leképezését és az önazonosság, a társadalmi szerepek kifejezését szolgálja. A kognitív nyelvészet a varianciát a jelentés felől közelíti meg. Alaptétele szerint a nyelvi kifejezések alkalmasak arra, hogy „a világ dolgait, jelenségeit különböző módon és különböző nézőpontból konstruálják meg szemantikai szerkezetükben (nyelven belüli és nyelvek közötti különbségekre is rámutatva" (Tolcsvai Nagy 2004: 144). A kognitív megközelítés, amint erre fentebb is utaltunk, sok azonosságot mutat az orosz Bondarko szemantikaimezö-elméletével (vö. Bondarko 1990).

A variativitás kérdésének tudománytörténetét vizsgálva azt is látnunk kell azonban, mint ahogyan azt az általános nyelvészeti kutatásokat végző Gak már említett könyvében (1998) megállapítja, hogy a variativitás - mint a nyelv alapvető sajátossága - anynyira általános, hogy nem lehet csak az egyes nyelvi tényekre leszükítve elszigetelten vizsgálni, hanem a variológia mint a variativitás elméletével foglalkozó új tudományág, önálló elméleti tudományos diszciplína keretein belül kell tanulmányozni.

A későbbi orosz szakirodalomban megjelenik a variantológia müszó is a tudományág megnevezésére (Golev-Kim 2009: 12). A variantológia mint önálló nyelvészeti diszciplína kutatási tárgyát az egyes nyelvi elemek variativitásának mint univerzális sajátosságnak a kutatásában határozza meg. Ennek keretein belül tárgyalja a variativitást mint a nyelvi elemek létének és funkcionálásának módját, a nyel- 
vi rendszer alapvető sajátosságát. Ez egybeesik Gak (1998) és Szolncev (1997) variativitásról adott meghatározásával, valamint Jarceva (1983) véleményével a terminológiai kérdésekkel kapcsolatban.

A variantológia a variativitáson belül hagyományosan két jelenségcsoportot vizsgál: 1. a nyelvi rendszer felöl a beszédtevékenység felé haladva a nyelv rendszerszerü sajátosságainak a beszéd szintjén történő megvalósulását; 2. a nyelvi elemek változását az azonos tartalmú nyelvi elemekkel korrelációs viszonyban, és fordítva: a tartalom módosulását az azonos hangtestü elemekkel korrelációban.

A variantológiának nevezett diszciplínának a legkidolgozottabb része e korrelációs viszony alapján az akcentus, így a variantológia elsősorban a fonológia keretein belül fejlődött, a fonéma (invariáns) / allofón (variáns) viszony vizsgálatával. Ezt követően terjedtek ki a variantológiai vizsgálatok a lexikológia, majd a morfológia és a szóképzés területére (vö. a Prágai Nyelvészkör kutatásaival, Péter 1980). Ezeken a szinteken a kutatások legfontosabb tárgya a nyelv lexikai és morfológiai elemeinek a korrelációja a hangzási oldal és az eltérő tartalmak ingadozásával (Golev-Kim 2009: 12).

A fenti leírásból egyértelmüvé válik, hogy a nyelvi variativitás kérdéseivel foglalkozó tudományág elnevezései (variativitás, variációs grammatika, variációs nyelvészet, variológia, variantológia), ha nem is variánsai egymásnak, mivel a fogalmat nem mindig azonos szempontokból határozzák meg, de szinonimáknak tekinthetjük őket.

\subsection{Nyelvi norma és variativitás}

A nyelvi variativitás meghatározásának során elengedhetetlen a nyelvi normához való viszonyának a tisztázása is. Erre azért van szükség, mert a nyelvi variánsok sok esetben a nyelvközösség egésze számára ismert sztenderd ellenében ható, de a különböző nyelvváltozatokban müködő szabályrendszer(ek)hez igazodó szituációs, csoportspecifikus, illetve funkcionális változatok, azaz müködésük módja és funkcióik csak a nyelvi norma viszonylatában érthetők meg jobban. A különböző variánsok használata szociokulturális meghatározottságú, így vizsgálatuk során figyelembe kell venni a beszélők képzettségét, foglalkozását, korát, nemét, lakóhelyét és más tényezőket is.

A nyelvészeti szakirodalomban a normának általában két alapvető értelmezésével találkozunk: 1. A lexikonokban, szótárakban rögzített elöírások, szabályok rendszere. 2. Az a nyelvhasználat, amely rendszeresen ismétlődik a beszélők verbális interakciójában (vö. Kardos 1992: 163). Az első értelmezés a langue síkján a nyelvi elemek használati szabályait rögzíti, a második értelmezésben a norma szabályozza a nyelvi rendszernek a beszédben leképeződő müködését is. A beszélő a norma alapján választja ki a különböző diskurzusokban felhasználható nyelvi elemeket, valamint szabályozza az elemeknek a nyelvi rendszer által meghatározott müködési módját (szabályrendszerét).

Az előíró nyelvészet a normával kapcsolatban olyan nyelvhelyességi szabályokat fogalmaz meg, amelyeket a beszélőknek be kell tartaniuk. „A nyelvmüvelő számára a nyelv konvenciók rendszere, de figyelmének középpontjában nem bár- 
milyen konvenciórendszer áll, hanem elsősorban a presztízsként elfogadott standard nyelvváltozat rendszere, amely ebben a felfogásban egyben fenntartó norma is" (Ladányi 2004: 113).

Normája minden nyelvváltozatnak van, de egységesült, kodifikált normával csak a sztenderdnek nevezett (köznyelvet és irodalmi nyelvet is magába foglaló normatív) nyelvváltozat rendelkezik (vö. Kiss 2003: 27). Bańczerowski Janusz elkülöníti egymástól a mintanormát és a használati normát: a korábban eszményinek tekintett (vö. Benkő 1988) mintanorma az elit nyelvhasználat kielégítésére szolgál, a használati norma pedig általános jellegü (vö. Bańczerowski 1998: 130-1). Kognitív nyelvészeti szempontból a norma célnorma és elvárásnorma, ismeret, tudás, ítélet és minta is egyben (vö. Tolcsvai Nagy 1998: 71). A nyelvi normával kapcsolatban tehát nemcsak egy normáról, hanem összetett normarendszerről kell beszélnünk.

\subsection{Nyelvi variativitás - nyelvi variabilitás}

A variabilitás és a variativitás fogalmak a magyar és a nemzetközi szakirodalomban gyakran egymás szinonimáiként szerepelnek. A variabilitás müszó a nyelvészetben azt a lehetőséget jelöli, amikor egy önálló nyelvi egység különféle variációkban realizálódhat (vö. Adger 2006: 503). A variabilitást ezért váltakozó realizációnak is nevezhetjük (vö. Borbély-Vargha 2010: 455), amelynek során egymással szoros kapcsolatban álló nyelvi változatok jönnek létre. A variabilitás az összes nyelvi szinten megfigyelhető a hang és a jel képzésének egyedi részleteitől a nyelvi jel vizuális és auditív feldolgozásáig (vö. Wolfram 2006).

A nyelvi variativitás - a nyelvi variabilitáshoz hasonlóan - az összes nyelvi szint létezésének és müködésének módjaként leírható, de csak azok a nyelvi változások sorolhatók a körébe, amelyek során a nyelvi jelenségek bizonyos alaki és jelentésbeli tulajdonságai is változatlanok maradnak, azaz a variativitás során állandó és változó tényezőknek egyszerre kell megjelenniük.

Szolncev szerint a nyelvészeti szakirodalomban a variativitás fogalmát kettős értelemben használják:

1. Mindenfajta evolúció eredményeképpen létrejövő nyelvi változás jellemzője.

2. A szinkrón nyelvi jelenségek létezésének és müködésének módja (vö. Szolncev 1984: 32; 1997: 60).

A nyelvi variativitást célszerü szinkrón nyelvi síkon, a mai nyelvi normákon belül vizsgálni, a variánsok/variációs sorok tagjainak történeti kontrasztív elemzését sem szabad azonban figyelmen kívül hagyni. A variativitás legcélravezetőbb vizsgálati módszerének tehát a dinamikus szinkrónia tekinthető (vö. Gorbacsovics 1978/98: 5).

A variabilitás és a variativitás fogalmak különbségeik ellenére bizonyos jegyekben azonosságot is mutatnak. Ilyen például az individuális és a csoportos változás. Az individuális változás során az egy adott nyelvhasználóra jellemző változat kialakulása figyelhető meg, a csoportos változás pedig a nyelvhasználók egész csoportjára, osztályára jellemző változatokat eredményez (vö. Gak 1998: 367). 
A fent leírtak alapján megállapíthatjuk, hogy a nyelvi variabilitás tágabb kategória, amelybe a variativitáson kívül más nyelvi jelenségek is beletartoznak, amelyektől azonban a variánsokat meghatározott szempontok alapján el kell különítenünk.

\subsection{Nyelvi variánsok és nyelvi változók}

William Labov a hetvenes évek elején megfogalmazta a kérdést: miért van az, hogy az egyik beszélö valamit így mond, a másik pedig máshogyan? (vö. Lavandera 1978: 171). A válasz a következő: a beszélő a rendelkezésére álló nyelvi elemek közül a kommunikációs helyzetnek megfelelően válogat. Választásra azonban csak akkor van lehetőség, ha legalább két változat áll a beszélő rendelkezésére (vö. Kiss 2002: 61), két lehetőség van ugyanazon dolog kifejezésére (vö. Labov 2004: 8). „A nyelvi változó alternatív nyelvi lehetőségek - legalább kéttagú - együttese egyazon dolog, jelenség, funkció kifejezésére. A nyelvi változó olyan nyelvi egység, amelynek azonosítható változatai vannak" (Wardhaugh 2002: 122). A nyelvi változatok egyformán müködőképesek, felcserélhetők egymással, társadalmi megítélésük azonban különbözik. A változatok egyike általában megfelel a kodifikált sztenderdnek, a többi eltér tőle. Az eltérés lehet stigmatizált vagy semleges (vö. Göncz 2001: 152). A nyelvi változók tagjai kapcsán tehát a szemantikai ekvivalencia mérvadó, hiszen azok felcserélése esetén a referenciális jelentésnek változatlannak kell maradnia (Wolfram 2006).

Mivel azokat a változókat is érdemes számításba venni, amelyek változatai több nyelvváltozatban/nyelvben élnek, azt is meg kell határoznunk, hogy a választási lehetőségek milyen keretek között alkotnak változót, azaz ha a különböző nyelvváltozatokat beszélök minden nyelvi környezetben ugyanúgy fejeznek ki valamit, akkor is beszélhetünk-e nyelvi változóról? A válasz igen, mert az egyes alternatívák használói számára választási lehetőségként mindig rendelkezésre áll a sztenderdben használatos változat. Ha a sztenderd nyelvváltozatban használt változat csak egyetlen más nyelvváltozatot használó beszélőnél is megjelenik, már nyelvi változóról kell beszélnünk (vö. Kalcsó 2007: 18). Ez a megállapítás is igazolja, hogy a variánsok vizsgálata során a sztenderd nyelvváltozat viszonyítási alapként való megjelölése elengedhetetlen.

A nyelvi változókról általánosságban elmondottak a variánsok esetében is megállják a helyüket, ugyanis a variánsok olyan nyelvi változatok, melyek közül a beszélő a konkrét kommunikációs helyzet függvényében választja ki a megfelelőt. Így lehetnek köztük stigmatizált (adsz/adú) és semleges (várj/várjál) alakok is. Arról azonban nem szabad megfeledkeznünk, hogy minden variáns egy nyelvi változó változata (ôt/ötet/itet), de nem minden nyelvi változat variáns, hanem például egy másik lexéma szinonimája (fejsze-szekerce). A variánsok esetében tehát szem előtt kell tartanunk azokat a kritériumokat (nem morfémaértékủ részleges alaki eltérés, illetve a denotatív jelentések azonossága), amelyek megkülönböztetik öket a többi nyelvi változótól.

\subsection{A nyelvi variánsok és az invariáns kapcsolata}

A variativitás terminológiájában a nyelvi variáns mellett az invariáns fogalma is fontos szerepet játszik, amelyet - a többi alapfogalomhoz hasonlóan - szintén a ter- 
mészettudományi terminológiából kölcsönzött a nyelvészeti szakirodalom. A rendszer szintjén müködő invariáns fogalmát értelmezve Szolncev megállapítja, hogy az invariáns a minket körülvevő világban nem létezik mint önálló dolog, azaz nem etalon, hanem absztrakció. Az invariáns a viszonylag egynemü dolgok osztályának a megnevezése. A szerző megállapítja, hogy az invariánsok azonban nem abszolút változatlanok, nagyságuk a kontextus elemeinek kölcsönhatása következtében változhat (Szolncev 1997: 60).

Bondarko (2000: 45) a grammatikai invariativitásról szólva az invariánst úgy értelmezi, mint a rendszerszintű elemek (nyelvi és beszédegységek, osztályok és kategóriák, ezek jelentéseinek és funkcióinak) jellemzőjét vagy jellemzőinek együttesét, amelyek állandóak maradnak mindenfajta olyan változás következtében is, amelyek a rendszer és a környezete kölcsönhatásának következtében mennek végbe.

A különböző osztályokat alkotó elemek, amelyek az invariánshoz viszonyítva variánsok, egyszerre viselik magukon az általános és az egyedi jegyeket. A konkrét variánsoknak, bár ugyanannak a lényegnek a megnyilvánulásai, egyedi létük van, és viszonylag önálló kapcsolatuk az őket körülvevő világgal. Minden variáns mint valamilyen variációs sor tagja egyszerre hordozza a közös és egyedi jegyeket - a variánsét és az invariánsét is. Az invariáns nem egy a variánsok közül, hanem magasabb fokon álló absztrakció (Lehmann 2009), az alakváltozatok közül a legtipikusabb (elvont és állandó), az adott kategóriát reprezentáló változat (vö. Laczkó 2000: 42).

Az invariáns azonban nemcsak absztrakt, hanem szemiotikai jellegü is lehet (vö. Iturrioz Leza - Skopeteas 2000: 237-8): az első esetben arról van szó, hogy egy jelenség formailag többféleképpen kifejezhető - a német nyelvben például a $v / f /$-nek (von, Vogel, Volk) és /v/-nek (Vulkan, Vakuum) is ejthetö -, a másodikban pedig az egyes fonémáknak és ejtésváltozataiknak, illetve a lexémának mint elvont szótári egységnek és különböző realizációinak (pl. nehmen $\rightarrow$ nehme, nimmst, nahm, nimm stb.) a viszonyáról beszélhetünk.

Az invariánst néha prototípusnak is nevezik. A két fogalom bizonyos szempontból rokon, de nem azonosak. Az invariáns - prototípus - variáns fogalomhármas hierarchikusan épül egymásra Bondarko funkcionális szemantikai rendszerében (vö. Bondarko 2000: 49). Bondarko szerint a funkcionális-szemantikai mezők centrumában elhelyezkedő, grammatikai eszközökkel kifejezett alakok invariánsai a közelebbi periférián elhelyezkedö lexikai-grammatikai eszközökkel kifejezett variánsoknak, ezek a variánsok pedig invariánsai a távolabbi mezőkön elhelyezkedő, ugyancsak különböző eszközökkel kifejezett variánsoknak.

\subsection{A nyelvi variánsok meghatározása}

A nyelvi variánsok különböző típusainak ismertetése elött meg kell fogalmaznunk egy adekvát definíciót, ugyanis ahogy a fentiekben már többször utaltunk rá, a szakirodalomban - mind a magyar nyelvüben, mind pedig a nemzetköziben - sok terminológiai pontatlansággal, átfedéssel találkozunk a szóban forgó nyelvi jelenséggel kapcsolatban. A feladat nem egyszerü, mivel a nyelvészetben nincs egy általánosan és egységesen elfogadott variánsdefiníció. Ennek egyik lehetséges oka, hogy a különböző nyelvi szintek variánsai más-más alaki és szemantikai tulajdonságok- 
kal rendelkez(het)nek. Mivel a variánsokat is érintő legtöbb nyelvészeti kutatás a lexémaszintre összpontosít, ezért ennek a nyelvi síknak a variánsaival kapcsolatban találjuk a legpontosabb definíciót a szakirodalomban: A lexikai variánsok olyan nyelvi változatok, amelyek alakilag nagyon hasonlóak (csak részleges, fonetikai, de nem morfémaértékü alaki eltérést mutatnak), referenciális (denotatív) lexikai és grammatikai jelentéseik teljesen azonosak, pragmatikai jelentéseik azonban eltéröek, azaz közöttük az egyes nyelvrétegbeli kommunikációs helyzetekben való felhasználhatóságukban mutatkozik különbség (vö. Lörincz J. 2009: 110). Ez a definíció kiindulási pontul szolgálhat a többi nyelvi szinten megjelenő variáns szemantikai és alaki tulajdonságainak a meghatározása során, de azokra teljes mértékben nem alkalmazható. A fonémavariánsoknak ugyanis például a képzési helye vagy módja a legtöbb esetben közel azonos (ezzel együtt pedig a funkciójuk is), önálló jelentésük viszont nincs, mivel jelelemek. A szövegvariánsokkal kapcsolatban viszont azt mondhatjuk, hogy két szöveg akkor tekinthető egymás variánsának, ha jelentéseik megegyeznek, a jelentésbeli azonosságnak azonban az alaki hasonlóság nem szükségszerü velejárója. A variánsok egy részét tehát alaki, másokat jelentésbeli, megint másokat alaki és jelentésbeli hasonlóság/azonosság is jellemez. A nyelvi azonosság feltételeként a variánsok esetében tehát azok referenciális értékazonossága mérvadó, szociális és stilisztikai (más szóval pragmatikai) jelentésük alapján viszont szembeállíthatók egymással (vö. Lavandera 1978: 174).

A német nyelvü szakirodalomban a következő variánsdefiníciókkal találkozunk: 1. Két kifejezés akkor tekinthető egymás variánsának, ha bizonyos vonatkozásban azonosak, azaz szemantikailag ekvivalensek (W. Klein 1976: 42). 2. A variánsok olyan nyelvi elemek, amelyek nem léphetik át a (fonéma- és morféma-) rendszer határait, hanem csak a struktúrához tartozó, saját pozíciójukat megtartó elemekként jöhetnek létre, hiszen esetükben a funkcionális ekvivalencia mérvadó (Henn-Memmesheimer 1998: 9). 3. Variánsokon az egyes nyelvi szintek elvont egységeinek különböző realizációit értjük (Knipf-Komlósi - V. Rada - Bernáth 2006: 27). 4. Két nyelvi elem akkor tekinthető egymás variánsának, ha ugyanazt a funkciót töltik be a szövegben, azaz funkcionálisan ekvivalensek (vö. Lehmann 2009). Jól látható azonban, hogy ezekben a definíciókban a variáns terminus csak részben azonos az általunk meghatározottal, hiszen a variáns müszó mindegyik esetben a szociolingvisztikai szakirodalomban nyelvi változónak nevezett nyelvi jelenségeknek egy tágabb értelemben vett osztályát is jelöli. Klein fentebb említett munkájában a variánsok kapcsán a pragmatikai ekvivalenciával is foglalkozik, ami a példái alapján a szintaktikai szinonimitáshoz kapcsolható, mivel szerinte a pragmatikai ekvivalencia esetében a forma különböző, de a jelentés azonos (vö. W. Klein 1976: 42).

A másik három hivatkozott munkában a variánsok definíciója a fonémák és a morfémák szintjén helytálló, hiszen bennük a fonémavariánsok az allofónokkal, a morfémavariánsok az allomorfokkal azonosak, ám a lexikai szinttől kezdve a lexikai és szintaktikai variáns megnevezés már nemcsak az allolexákat (szóvariánsokat) és a szószerkezeti, illetve a mondatvariánsokat foglalja magába, hanem a lexikai és szintaktikai szinonimákat is (vö. Henn-Memmesheimer 2008: 13-6; Knipf-Komlósi - V. Rada - Bernáth 2006: 26-8; Lehmann 2009). A terminológiai 
többértelmúség a német nyelvü szakirodalom más képviselöinek esetében is megfigyelhető (vö. még Crévenat-Verner 2002: 87-92).

A magyar szakirodalomban is sok esetben találkozhatunk terminológiai pontatlanságokkal, amelyek során a variánsokhoz hasonló, azoktól azonban mégis különböző nyelvi jelenségeket is variánsoknak nevezik. A kutatók a variáns fogalmát legtöbbször a szinonimával cserélik fel (vö. Benkő 1988: 68; Dömötör 2004: 72; Gombocz 1903/1997: 60; Haader 2001: 367; Hadrovics 1992: 93), más esetekben a poliszémiával hozzák kapcsolatba (lásd szemantikai variánsok), néha pedig a nyelvi változók minden típusát variánsnak tekintik (vö. Lanstyák 2009: 19; Kiss 2008: 260; Szathmári 1999: 301). Az is előfordul azonban, hogy a nyelvészek nem feltételeznek szoros kapcsolatot olyan nyelvi elemek között, amelyeket egymás variánsaiként kellene kezelni. Szabómihály Gizella és Lanstyák István (vö. 2011: 115-6) a nyelvi változókat funkció- és jelentésazonosságuk alapján két csoportra osztja: szoros változókra és laza változókra. A szoros változók esetében a funkcionális és jelentésbeli azonosság egyértelmü, míg a laza változók esetében (megrendezésre kerül-megrendezik, várj-várjál) nem. Ezzel a megállapítással nem érthetünk egyet, ugyanis véleményünk szerint mind a szintaktikai (szószerkezeti), mind pedig a morfológiai (szóalak-) variánsok esetében a jelentésbeli azonosságon kívül a nagyfokú alaki azonosság is azok szoros összetartozását bizonyítja (vö. Lőrincz J. 2004a).

A nyelvi variativitással kapcsolatban tisztáznunk kell az alakváltozat terminus jelentését is, amely nem minden esetben azonos a variánssal, akkor sem, ha a megnevezés magában hordozza a nagyfokú alaki azonosság tényét. Az ÉrtSz. szerint (vö. 1978: 106) alakváltozatok:

1. Mindazok a tőszók, amelyek minden jelentésükben és jelentésárnyalatukban egyeznek. Például: csend-csönd, ábrándozik-ábrándoz.

2. Az ilyen tőszók azonos képzővel ellátott származékai: csendes - csöndes, borotvál-beretvál.

3. Az ilyen tôszókkal vagy származékaikkal alkotott összetételek: csendháborítás - csöndháboritás, elcsendesedés - elcsöndesedés.

Grétsy László (vö. 1962: 19-20) és Károly Sándor (vö. 1970: 78) az alakváltozat megnevezést csak a variánsokra használja, Lanstyák István viszont egyes munkáiban (2006a) a variánsokra (infarktus - infarkt), másokban (2006b: 78) a variánsokra és az azonos tövü szinonimákra (gereblyél - gereblyéz) egyaránt alkalmazza.

A Magyar grammatika (MGr.) címü egyetemi tankönyv többféleképpen is megközelíti az alakváltozat fogalmát. Az egyik megközelítési mód azonosítja az alakváltozatokat a variánsokkal (alakváltozat = variáns = allomorf), a másik azonban különbséget tesz az alakváltozat (variáns) és az allomorf terminus között (vö. Laczkó 2000: 42-3). Ez utóbbi szemléletmód szerint az allomorfia kizárólag az alternációhoz kapcsolható, a variativitás azonban nem köthető grammatikai alapkategóriához: ,,a jövő időnek mint időviszonynak a magyarban variánsait tudjuk megkülönböztetni: analitikus morfológiai szerkezettel, szintagmával vagy a jelen idő transzpozíciójával is kifejezhető - ezek azonban egymásnak nyilvánvalóan nem alternánsai” (Laczkó 2000: 43). Itt egyértel- 
müen grammatikai szinonimitásról beszélhetünk, hiszen az azonos funkció betöltésére más-más kifejező eszközöket használunk, amelyek alakilag is különböznek egymástól. Például: Holnap elmégy hozzá. El fogsz menni hozzá. Ebből a gondolatmenetből látszik, hogy bár a variativitás és az alternáció (vö. Deme 1986) - valamint a szinonímia - egyes típusai mutatnak azonos jegyeket (az alternánsok az azonos morféma egymást váltogató alakjai, amelyek nagymértékủ alaki azonosságot és részleges alaki különbséget mutatnak), köztük mégis különbséget kell tenni. A variánsok az alternánsokhoz képest tágabb kategóriát képviselnek, a variáns ugyanis nem azonosítható az összes alternánssal, csak a funkciótlan tőalternánssal (vö. Lőrincz J. 2009: 102).

Tóth Etelka (vö. 2002: 17) az alakváltozat megnevezés egy szükebb és egy tágabb értelmezési lehetőségére is felhívja a figyelmet. Leírása alapján a szükebb értelemben vett alakváltozatok (ingadozásváltozatok/ingadozásvariánsok) felelnek meg a variánsoknak, amelyek egyben a funkciótlan szabad alternánsokkal is azonosak. A terminus tágabb értelmezése (amelyet munkájában mérvadónak tekint) azonban a funkciótlan szabad alternánsokon (variánsokon) kívül magába foglalja a funkciótlan kötött és a funkciós alternáció jelenségeit is. Tóth Etelka a Nyelvmüvelö kézikönyv (NyKk.) nyomán az alakváltozat terminust elkülöníti az alakpár terminustól. „Alakváltozatoknak tekintjük az olyan közös gyökerü párokat, amelyeknek tagjai között írásban is megnyilvánuló magán- vagy mássalhangzóbeli (például kötőhangzóbeli) eltérés van, önálló szóelem- vagy toldalékbeli különbség nincs. [...] A szóalakpárok olyan alakkettősök, amelyeknek tagjai valamely önállóbb szóelem, képző, jel stb. tekintetében különböznek egymástól, mégpedig úgy, hogy többnyire kisebb-nagyobb jelentéskülönbség is van köztük" (Grétsy-Kovalovszky 1980: 139). Az előbbi meghatározás értelmében tehát a variánsok az alakváltozatok közé, míg a szóhasadás körébe tartozó nyelvi jelenségek (apraja - aprója), a szinonim képzővel képzett azonos tövü szinonimák (zsibbasztóan - zsibbasztólag), valamint a paronímia tárgykörébe tartozó lexémák (helység - helyiség) az alakpárok közé sorolhatók. Tóth Etelka ugyan utal az alakpárok tagjainak denotatív jelentésbeli eltéréseire, mivel azonban munkájában elsődlegesen alaki szempontokra koncentrál, így az alakváltozatok jelentésviszonyaival bővebben nem foglalkozik (vö. Tóth E. 2002: 24).

A paronimák és az azonos tőből szinonim képzővel létrehozott szinonimák mellett nem minősülnek variánsoknak az olyan alakváltozatok sem, amelyek közül az egyik egy meghatározott nyelvtani alakhoz kötött (jön - jö, kel - kél). Ezeknek az alakpároknak az egyik tagja az a változat, amelyből a paradigma minden tagját képezzük, a másik azonban csak kijelentő mód jelen idő egyes szám harmadik személyben használatos (vö. Elekfi 1996: 294).

A variativitás kapcsán meg kell említenünk a különböző mértékü alak- és jelentéshasadást mutató alakváltozatok kérdését is, amelyek három csoportba sorolhatók: funkcionális elkülönülést mutató variánsok, a teljes szóhasadás körébe tartozó önálló lexémák, valamint a részleges alak- és jelentéshasadást mutató alakvariánsok. Az első esetben egy poliszém lexéma alakvariánsairól van szó, amelyek denotatív jelentései azonosak, de pragmatikai jelentéseikben eltérést mutatnak: kapsz - kapol. A második esetben önálló lexémák jönnek létre, amelyek esetében szinkrón nyelvi síkon teljes jelentéselkülönülés figyelhetö meg még akkor is, ha nagyfokú alaki hasonlóságot mutatnak: nevel-növel, megvesz-megveszik, jön-jö. A harmadik eset 
pedig a kettő közötti átmenetet képviseli, ugyanis nehezen dönthetö el, hogy két önálló lexémáról vagy egy lexéma alakváltozatairól van-e szó: átnyúl - átnyúlik, áldoz - áldozik (vö. Keszler 1974; Lőrincz J. 2004b, 2009: 103-8).

\subsection{A nyelvi variánsok típusai}

A variánsokkal kapcsolatos terminológia tisztázása után következzen a variánsok osztályozása először a magyar nyelvü szakirodalom alapján (vö. Lörincz-Jászay 2001; Lörincz J. 2009, 2010, 2011; Lörincz G. 2014, 2016):

1. Fonetikai/fonológiai variánsok:

a) egy fonéma különböző allofónjai: e/ä (pl. este/ästä)

b) az eltérés lexémaszinten jelentkezik a kiejtésben (ejtésvariánsok), a fonéma-összetételben vagy ezeknek a jellemzőknek a kombinációjaként: kötélen/kötelen, fonal/fonál, [kecske]/[këcske].

2. Morfológiai variánsok:

a) lexikai variánsok (szó- és szóalakvariánsok): csoda/csuda, ajtaja/ajtója

b) tőmorféma-variánsok: sugár-/ugárz-, tó/tav-

c) toldalékmorféma-variánsok: -ban/-ben, -nál/-nél

3. Szintaktikai variánsok: az azonos információtartalom más lexikai, grammatikai elemekkel való kifejezése:

a) szószerkezeti variánsok: javaslatot tesz / javasol

b) mondatszerkezeti variánsok: A viselkedésed felháboritó! / Felháborít engem, ahogy viselkedsz!

4. Szövegvariánsok: egy-egy szöveg azonos információtartalmú kisebb-nagyobb eltérést mutató változatai, átiratai

5. Nyelvváltozat-variánsok:

a) a magyar sztenderd különböző határon túli állami változatai,

b) a (magyar) nyelv horizontálisan és vertikálisan elkülönített változatai.

A felsoroltakon kívül megkülönböztethetünk még

6. Írásvariánsokat, amelyek szintén több nyelvi síkon is megjelennek:

a) Grafémavariánsok: $c z-t z-c$ (vö. Knipf-Komlósi - V. Rada - Bernáth 2006: 28).

b) Idegen eredetü szavak írás- és ejtésváltozatai: imázs imidzs, sztenderd/ standard (vö. Zsemlyei 2002/2009: 12).

c) Helyesírási variánsok: Nemzeti Színház / nemzeti színház, galántai Városi Hivatal / Galántai Városi Hivatal (vö. Misad 2009: 123; 2011: 135-45).

A fenti osztályozás kapcsán fel kell hívnunk a figyelmet arra, hogy a kiejtési variánspároknak nem mindegyike illik teljesen a rendszerbe, ugyanis közülük a legtöbb tagjai valóban csak pragmatikai jelentéseikben térnek el [nekem] - [nëkëm], mások azonban a homonímia jelentésviszonyába tartoznak [nëm]-[nem]. 
A német szakirodalomban többféle - a fentitől valamelyest eltérő - variánstipológiával találkozunk, amelyek közül az alábbiakban a dolgozatunk szempontjából két legfontosabbat részletezzük. Az első felosztás Muthmann nevéhez füződik. A szóban forgó párokat ő ugyan kettős alakoknak (Doppelformen) nevezi, de könyve bevezetőjében felhívja rá a figyelmet, hogy a terminus a nyelvtudományban általánosan elfogadott jelentésétől eltérően csak azokat a párokat sorolja ebbe a kategóriába, amelyek esetében vagy a kiejtés, vagy az íráskép, vagy egyszerre mindkettő változik (vö. Muthmann 1994: 4). A fenti kritériumok alapján három típust különít el (vö. 1994: 6-9), amelyek - a 3a csoport bizonyos elemeinek kivételével - azonosíthatók a variánsokkal, hiszen megfelelnek az általunk fentebb meghatározott kritériumrendszernek:

1. Kiejtésbeli variánsok: grob [gro:p/grop] 'durva'.

2. Helyesírási variánsok: Friseur/Frisör 'fodrász', krängen/krengen 'megdönt'.

3. Formavariánsok: Cabriolet/Kabriolett 'ua.', der Fleck/der Flecken 'folt'.

a) Szóképzési variánsok: hormonal/hormonell 'hormonális', Schankstube/ Schänkstube 'söntés', Kolonisation/Kolonisierung 'gyarmatosítás', Missbehagen/Unbehagen 'szorongó, rossz érzés'.

b) Ragozási variánsok: Lexika/Lexiken 'lexikonok', Generale/Generäle 'generálisok'.

A példák jól mutatják, hogy a 3a csoportban nem csak variánspárok vannak: a Kolonisation/Kolonisierung szóalakoknak a képzői, a Misbehagen/Umbehagen föneveknek pedig az igekötői állnak szinonim viszonyban egymással, ezáltal pedig a két-két szóalakot is szinonimáknak kell tekintenünk.

A másik felosztás W. P. Kleintől származik. A szerző kétséges eseteknek (Zweifelsfälle) nevezi azokat a különböző nyelvi szinteken megjelenő standardban használatos változatpárokat, -sorokat (szavakat, szóalakokat, mondatokat), amelyek elemeivel kapcsolatban a kompetens - anyanyelvi, de nem nyelvész - beszélőnek kétségei vannak, mivel nem tudja eldönteni, hogy egy konkrét kommunikációs helyzetben vagy szövegkörnyezetben melyikük a megfelelö, azaz adekvát. Ezeknek a pároknak, soroknak a tagjai a legtöbb esetben részleges alaki eltérést mutatnak, ami nem azt jelenti, hogy minden részleges alaki eltérést mutató pár besorolható ebbe a csoportba. Nem tartoznak ide például az agrammatikus (nyelvi tévesztésnek is tekinthetö) alakok és az úgynevezett minimálpárok sem. Fontos tehát leszögezni, hogy a két alak között erös szemantikai kapcsolatnak (sokszor teljes ekvivalenciának) is lennie kell (vö. W. P. Klein 2003: 7, 10-1). A szerző nyelvi szintek szerint a következő típusokat különíti el (vö. W. P. Klein 2018: 14-5):

1. Fonetikai változatok: Senf [-nf/mf] 'torma', Kaffee ['kafe / ka'fe].

2. Grafematikus változatok: im allgemeinen / im Allgemeinen 'általában', brustschwimmen / brustschwimmen / Brust schwimmen 'mellúszás'.

3. Flexiós változatok: dummer/dümmer 'buta / butább', ich laufe / lauf'futok'. 
4. Szóalkotási változatok: Schadenerzarz/Schadenserzarz 'kárpótlás', formell/ formal 'alaki, formális'.

5. Szintaktikai változatok: wir Deutsche / wir Deutschen 'mi németek', westlich Kölns / westlich von Köln 'Kölntöl nyugatra'.

6. Lexikai változatok:

a) monolexematikus: Quell/Quelle 'forrás', nutzen/nützen 'használ';

b) polilexematikus: Adresse/Anschrift 'cím', kehren/fegen 'söpör'.

Klein azonban szintén nemcsak a variánsokat, hanem a hasonló alakú nyelvi változók szélesebb körét is vizsgálja, amit jól szemléltet, hogy például lexikai szinten elhatárolja egymástól a mono-, illetve a polilexematikus változatokat: előbbiek ugyan eleget tesznek a variativitás kritériumainak (Friede/Frieden 'béke', gern/ gerne 'örömmel', der/das Teil 'rész'), utóbbiak azonban (Fleischer/Metzger 'hentes, mészáros', Mundart/Platt/Dialekt 'tájszólás, dialektus', Notebook/Laptop 'ua.') egyértelműen szinonimák. Ha az ilyen jellegü megkülönböztetést - a fonetikai és grafematikus sík kivételével - minden esetben szem elött tartjuk, akkor a rendszer maradéktalanul alkalmas a variánsok osztályozására (is). Klein ezen felül minden egyes nyelvi szinten további két szempont - a használat gyakorisága, illetve a használat kontextusa - szerint csoportosítja a nyelvi elemeket. Ezt azért tartja fontosnak, mert bár így is a sztenderd nyelvváltozat marad a viszonyítási alap, ennek ellenére a többi nyelvváltozat elemei sem stigmatizálódnak (a példaanyagban csak variánspárokat tüntetünk fel):

I. A használati gyakoriság, frekventáltság mértéke:

1. szabad variáció - mindegyik változat használatos és elfogadott: siebtel siebente 'hetedik', gern/gerne 'szívesen';

2. okozati variáció - az egyik elem gyakrabban használt, elfogadottabb a másiknál: das/der Balg 'irha, bör', magerer/magrer 'soványabb, karcsúbb', dubios/dubiös 'gyanús';

3. null-variáció - az egyik változat elfogadott (a sztenderd szemszögéböl), a másik nem: Felsblöcke/Felsblocks 'vándorkövek'.

II. A használat kontextusa:

1. stilisztikai variáció - az egyik elem konnotációja eltér a másikétól: baldmöglichst / möglichst bald 'minél hamarabb';

2. regionális variáció - az egyik elem köznyelvi, a másik nyelvjárási: Erlasse/Erlässe 'parancs, rendelet', die Ersparnis / das Ersparnis 'megtakarítás', Ochse/Ochs 'ökör';

3. szaknyelvi variáció - az egyik változat köznyelvi, a másik szaknyelvi: die Niete / der Niet 'szegecs';

4. beszélt nyelvi variáció - az egyik elem köznyelvi, a másik beszélt nyelvi: für das / fürs 'valakinek, részére', Jungen/Jungens/Jungs 'fiúk', Herumlaufen/rumlaufen 'futkosni';

5. történeti variáció - az egyik szó napjainkban standard, a másik a múltban volt az: Likör/Liqueur 'ua.', Frömmigkeit/Frommheit 'jámborság'; 
6. kiegészítő variáció - az egyik kontextusban az egyik, a másikban a másik elem adekvát: der/das Moment 'pillanat' (vö. W. P. Klein 2003: 19-20).

Az orosz szakirodalomban is többféle, részben kissé eltérö tipológiával találkozunk, amelyek közül most szintén csak a saját kritériumaink szempontjából két legjobban felhasználhatót részletezzük. Az orosz nyelvészeti terminológiai szótár (Rozental-Tyelenkova [szerk.] 1976) a következő variánstípusokat különíti el:

1. akcentológiai (kiejtésbeli): одновременно/одновременно (odnovrémenno/ odnovreménno) 'egyidejüleg';

2. fonetikai (fonematikus): ноль/нуль, туннель/тоннель (tunnel/tonnel) 'alagút'

3. ortoepikai: булочная/булощная (bulocsnaja/bulosnaja 'péksüteményeket árusító bolt'

4. morfológiai (grammatikai): глист/глиста (gliszt/glíszta) 'giliszta', искренно/искренне (íszkrenno/íszkrennye) 'őszintén' (itt az előbbi három típus keveredik)

5. szóképzési: полсотня/полусотня (polszotnya / poluszotnya) 'félszáz' (különböző morfémavariánsok összekapcsolódásával jönnek létre az összetett szavakban)

6. szemantikai: холодный ветер/холодный костюм/холодный климат (holódnij vétyer/holódnij kosztyúm / holódnij klimat) 'hideg szél, hideg (azaz a hideg elleni meleg!) kosztüm, hideg éghajlat'

A grammatikai variánsok elkülönítése Graugyina (1997) könyvében jóval pontosabb az előző felosztásnál:

a) szóragozási: движет/двигает (dvígaet/dvízset) 'mozgat';

b) szóképzési: полсотня/полусотня (polszotnya/poluszotnya) 'félszáz';

c) szintaktikai: две основные задачи / две основных задачи (dve osznovníje zadácsi/ dve osznovníh zadácsi) 'két alapvető feladat' (a számnevek egyeztetésekor, ha nőnemü a fönév, 2, 3, 4 után a melléknévi jelző lehet tsz. alanyeset és birt. eset is, mindkettő sztenderd forma).

Gak megállapítása szerint az alacsonyabb nyelvi szinteken létrejövő variánsok változásokat hoznak létre a magasabb szinteken is: „A változás (az új lényeg létrejötte) variánsként megjelenhet más (rendszerint magasabb) szinten. A fonémaváltozás morféma- vagy szóvariánst, a szó változása a kijelentés variativitását hozza létre, stb. [...] Így míg a tvó/rog / tvoró/g 'túró' - variánsok, addig a zámok/zamók 'vár / zár' - különböző lényegek" (Gak 1998: 368; ford. Lőrincz J.). A hangsúly helyének változása tehát olyan akcentológiai jelenség, amelynek eredménye nemcsak azonos denotatív jelentésü variánspár, hanem eltérő jelentésü homonimapár is lehet.

Meg kell jegyeznünk azt is, hogy a szakirodalomban elsősorban a poliszémák egyes jelentéseit nevezik szemantikai variánsoknak. Ilyen esetekben az invariáns a jeltárgyhoz legközelebb álló (prototipikus) denotatív jelentés, a többi jelentés, 
amelyek a jelentéshálón belül metaforikus vagy metonimikus kapcsolat révén függnek össze, ennek variánsa (vö. Lendvai 1998).

Végül a Jarošová által a szlovák nyelvü szakirodalomban leírt összefoglaló jellegü tipológiát ismertetjük. A szerző a variánsok alábbi típusait különíti el (vö. Jarošová 2009):

1. Fonológiai helyzettől függő (morféma)variánsok: például bank-ár 'ua.', bábk-ar/bábk-ár 'bábszínész', omietk-ar 'vakoló', betón - betonár 'betonozó', pismak/písmák/pismák'olvasott ember'.

2. Fonematikus variánsok: blesknút'/blesnút' 'csillog', čačina/čečina 'fenyögally', budzogáň/buzogán̆ 'ua.', džadky/džatky 'egyfajta krumplis tészta'.

3. Grafikai variánsok:

a) a kölcsönszavak írásváltozatai: džez/jazz, erobik/aerobik, focal/FOCAL/ Focal 'egyfajta programozási nyelv';

b) a kölcsönszavak külön- és egybeírt változatai: betaverzia / beta verzia, aupair / au-pair / au pair;

c) szlovák szavak külön- és egybeírt változatai: nabielo / na bielo 'fehérre', bohvieako/bohvie 'isten tudja, ki', cikcak/cik-cak;

d) a köznevesülő tulajdonnevek írásváltozatai: Intercity/intercity.

4. Szóalkotási variánsok:

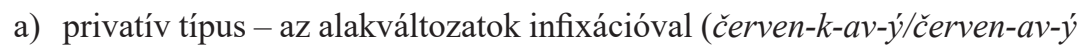
'pirosra festett', bahn-ist-ý/bahn-it-y' 'iszapos, iszappal teli', cel-učičk-ý/ cel-učký/cel-ulink-ý/cel-unk-ý 'egészke, egészecske'), egy másik szuffixum segítségével (bogomil/bogomil-ec 'eretnek szekta követője, bogumil', bežsv-íkov-ý/bezšv-ov-ý'varrat nélküli'), a prefixum vokalizációjával (bezo-dný/bez-dný 'feneketlen', rozotriet'/roztriet' 'szétkenni') vagy rövidüléssel (glazovat'/glazúrovat' 'zománcoz', kopírka/kopírovačka 'fénymásoló ') jönnek létre;

b) ekvipolens típus - a párok tagjaiban eltérő szuffixumok vannak: cuc-k-at'/ cuc-l-at' 'szopogat ', flaka-t-ý/flaka-v-ý 'foltos', barinatý/barinastý 'ingoványos ', blonkýna/blondýnka 'szőke nő', citovo/citove 'érzelmileg'.

5. Morfológiai variánsok:

a) nembeli - egy fónévnek két grammatikai neme van, amelyek a teljes ragozási paradigmát meghatározzák: ten fald / tá falda 'görbület, hajlás' az első hím-, a második nőnemü, ten brt / tá brt' 'méhek odúja' - az első hím-, a második nőnemü, artikul/artikula 'szerződés, törvény bekezdése' - az első hím-, a második nőnemü)

b) alakvariánsok / kettős alakok - ugyanannak a főnévnek két egyenértékü grammatikai alakja van (brloha/brlohu 'odúba', dedičia/dediči 'örökösök', dverami/dvermi 'ajtókkal'), illetve az alakváltozatok más-más minta szerint ragozódnak (askét/askéta 'ua.', cieňa/cieň 'fészer').

Jogosan merül fel a kérdés, hogy az angol (nyelvü) szakirodalmi vonatkozások miért nem jelennek meg a dolgozatban. A válasz egyszerü: azért, mert a fentiekhez hasonló, minden (vagy legalább kettőnél több) nyelvi szintre kiterjedő rend- 
szerezést hosszas kutatómunka után sem találtunk eddig a szakirodalomban, ami természetesen nem feltétlenül jelenti azt, hogy nincs is ilyen. A lexikai szintű variánsokkal kapcsolatos szükebb értelmezéssel (amely elhatárolja az alakváltozatokat és a szinonimákat) például egyedül Harpringnál (2010: 29) találkoztunk (pl. pediatrics/ paediatrics, Romania/Rumania/Roumania), aki az alakváltozatokat az ekvivalencia keretén belül tárgyalja. Ugyan Hegedüs könyve is tartalmaz néhány utalást az angol nyelvben előforduló variánspárokra, de a szerző azokat a dublettekkel (kettős alakokkal) kapcsolatban, tágabb összefüggésrendszerben említi. Utal rá, hogy a variánsnak tekinthető párok például brit-amerikai nyelvi viszonylatban vizsgálhatók írás- (cheque/check 'sakk, akadály, csekk') vagy lexémaváltozatok (gaol/jail 'börtön') formájában (vö. Hegedüs 2017: 33-5).

\section{5. Összegzés}

Tanulmányunk első felében a nyelvi variativitás elméleti vonatkozásaival foglalkoztunk. A variativitás kérdéseinek vizsgálata során a nyelvi szimmetria/aszimmetria jelenségéből indultunk ki, szem előtt tartva a nyelvi változás mechanizmusát is, majd a variatitivásnak a variabilitáshoz és a normához füződő kapcsolatát tisztáztuk. Ezek után megvizsgáltuk az alakváltozatok helyét a nyelvi változók között, illetve a variánsoknak az invariánshoz füződő viszonyát. Munkánk második részében a variánsok tipológiáját ismertettük a hazai, illetve a nemzetközi szakirodalom alapján.

Ugyan többször utaltunk arra, hogy a nyelvi variativitással kapcsolatban mind a hazai, mind pedig a nemzetközi szakirodalomban sok terminológiai átfedés található, az alakváltozatokkal azonos jegyeket (is) mutató nyelvi jelenségek részletes elemzése és tárgyunktól való elhatárolása ennek a tanulmánynak a kereteibe azonban nem fért bele. A poliszémia, a szinonímia, a paronímia, a részleges alak- és jelentésmegoszlás, a szóhasadás, a dublettek, illetve a konvergens alak- és jelentésfejlödés variánsokhoz füződő kapcsolatrendszerének a hazai és nemzetközi szakirodalmi vonatkozásokon alapuló ismertetése a fentiekhez hasonló alapos kifejtést igényel, ezért egy másik tanulmány tárgyát kell képeznie.

Arra is utalnunk kell, hogy a nyelvi variativitás nemcsak egy nyelv sztenderd változatán belül, hanem az adott nyelv különböző nyelvváltozatainak (pl. sztenderdnyelvjárás, nyelvjárás-nyelvjárás stb.), sőt akár két nyelvnek (pl. a szlovákiai magyar kisebbség körében a magyarnak és a szlováknak) a viszonylatában is megfigyelhető. Utóbbi esetben leginkább a kontaktusváltozat-párok érdemelnek figyelmet, mivel közöttük szép számmal találhatóak köznévi - például internát/internátus, prax/praxis (vö. Lanstyák 2006c: 39-40) -, illetve tulajdonnévi - például Bese/Beša, Ekecs/ Okoč (vö. Török 2010: 71; 2012: 129; 2013: 85) alaki kölcsönszók, vagyis kontaktusvariánsok, de ezek vizsgálata mellett például a szlovák és a magyar nyelv alakváltozatainak (pl. ma/mňa - engem/engemet, t’a/teba - téged/tégedet) kontrasztív szempontú összevetése is érdekes lehet (vö. Misadová 2011: 85; Tóth S. J. 2017: 117). Ezek a nyelvi jelenségek azonban szintén olyan összetettek, hogy részletes bemutatásuk csak egy újabb önálló tanulmányban lehetséges. 


\section{SZAKIRODALOM}

Adger, David 2006. Combinatorial Variability. Journal of Linguistics 42: XXX/3: 503-30. https://doi.org/10.1017/S002222670600418X 503-30.

Bally, Charles - Балли, Ш. 1955. Общая лингвистика и вопросы франиузского языка, Москва.

Bańczerowski Janusz 1998. Néhány gondolat a nyelvi és a kommunikációs normákról. Magyar Nyelvör 122: 129-33.

Benkő Loránd 1988. A történeti nyelvtudomány alapjai. Nemzeti Tankönyvkiadó, Budapest.

Bondarko, A. V. - Бондарко, А.В.В. 1990 (отв. ред.). Теория функииональной грамматики. АН СССР Интитут Языкознания. «Наука. Ленинградское отделение», Ленинград.

Bondarko, A. V. 2000. К вопросу об инвариантности грамматичесих значений. Nyelv, aspektus, irodalom. In: Györke Zoltán (szerk.): Köszöntö könyv Krékits József 70. születésnapjára. Készült a Szegedi Tudományegyetem JGYTF Kara Orosz Nyelv és Irodalom Tanszékén, Szeged, 45-9.

Borbély Anna - Vargha András 2010. Az l variabilitása öt foglalkozási csoportban. Kutatások a Budapesti Szociolingvisztikai Interjú beszélt nyelvi korpuszban. Magyar Nyelv 106: 455-70.

Bynon, Theodora 1977. Historical Linguistics. Cambridge University Press, Cambridge. http://books.google.sk/books?id=A-dB-7CYMwcC\&printsec=frontcover\&hl=hu\&sourc $\mathrm{e}=$ gbs_ge_summary_r\&cad $=0 \# \mathrm{v}=$ onepage $\& \mathrm{q} \& \mathrm{f}=$ false (Letöltés ideje: 2019.04 .9 .)

Crévenat-Werner, Danielle 2002. Lexikalische und morpho-phonologische Varianten im Straßburger Sprachraum. In: Glaser, Elvira - Ott, Peter - Schwarzenbach, Rudolf (eds.): Alemannisch im Sprachvergleich: Beiträge zur 14. Arbeitstagung für alemannische Dialektologie in Männedorf (Zürich). Steiner Verlag, Stuttgart, 87-101. https://books. google.hu/books?id=BQsk-5RpFZgC\&pg=PA89\&lpg=\%20PA89\&dq=Alemannisch $+\mathrm{i}$ $\mathrm{m}+$ Sprachvergleich ++ Beitr $\% \mathrm{C} 3 \% \mathrm{~A} 4 \mathrm{ge}+\mathrm{zur}+14 .+$ Arbeitstagung $+\mathrm{f} \% \mathrm{C} 3 \% \mathrm{BCr}+\ldots+$ vari anten\&source $=$ bl\&ots $=$ oLz1Cc_kYh\&sig $=$ b7FVF3KTWWhAFAtyKzNpnGnxNDs\&hl $=$ hu\&sa $=X \&$ ei $=35$ nuUbS2BoLWtAbIsoCQDQ\&ved $=0$ CD8Q6AEwAw\#v=onepage \&q $=$ Alemannisch $\% 20 \mathrm{im} \% 20$ Sprachvergleich $\% 20 \% 20 \mathrm{Beitr} \% \mathrm{C} 3 \%$ A4ge $\% 20 \mathrm{zur} \% 2014 . \% 20$ Arbeitstagung $\% 20 \mathrm{f} \% \mathrm{C} 3 \% \mathrm{BCr} \% 20 \ldots \% 20$ varianten $\& \mathrm{f}=$ false (Letöltés ideje: 2019.05 .19$. )

Deme László 1986. A beszéd és a nyelv. Tankönyvkiadó, Budapest.

Dömötör Adrienne 2004. Mondatszerkezeti szinonímia és formai változatok. In: Gecső Tamás (szerk.): Variabilitás és nyelvhasználat. Segédkönyvek a nyelvészet tanulmányozásához XXXIV. Tinta Könyvkiadó, Budapest, 73-9.

Dürscheid, Christa - Schneider, Jan Georg 2019. Standardsprache und Variation. Narr Francke Attempto Verlag GmbH + Co. KG., Tübingen.

Elekfi László 1996. Részleges szóhasadások mint határesetek. Magyar Nyelv 92: 286-96.

Elspaß, Stephan - Dürscheid, Christa - Ziegler, Arne 2017. Zur grammatischen Pluriarealität der deutschen Gebrauchsstandards - oder: Über die Grenzen des Plurizentrizitätsbegriffs. Heinz Sieburg - Hans-Joachim Solms (Hrsg.): Thema des Heftes: Das Deutsche als plurizentrische Sprache. Ansprüche - Ergebnisse - Perspektiven. Zeitschrift für deutsche Philologie. Sonderheft 136: 69-91.

[ÉrtSz. I.] = Balázs János - Martinkó András - Grozdits Judit - Lengyel András - Bíró Izabella (szerk.) 1978. A magyar nyelv értelmezö szótára I. Akadémiai Kiadó, Budapest.

Gak, V. V. - Гак, В. В. 1990. Асимметрия. In: Лингвистический энциклопедический словарь. Под ред. В.Н. Ярцевой, Советская Энциклопедия, Москва.

Gak, V. V. - Гак В. В. 1998. Языковые преобразования. Школа: «языки русской культуры», Москва. 
Golev, N. D. - Kim, L. G. - Н. Д. Голев, Л. Г. Ким 2009. Вариативно-интерпретационное функционирование текста (к вопросу о расширении границ лингвистической вариантологии). Вестник Челябинского государственного университета. 2009. № 27 (165). Филология. Искусствоведение. Вып 34: 12-20.

Gombocz Zoltán 1903/1997. Nyelvtörténet és lélektan. Wundt néplélektanának ismertetése. In: Kicsi Sándor András (szerk.): Jelentéstan és nyelvtörténet. Válogatott tanulmányok. Akadémiai Kiadó, Budapest, 9-72.

Gorbacsovics, K. Sz. - Горбачевич, К.С. 1978/1998. Вариантность слова и языковая норма. Наука, Ленинград.

Grétsy László 1962. A szóhasadás. Akadémiai Kiadó, Budapest.

Graugyina, L. К. - Граудина, Л. К. 1997. Варианты. «Русский язык - энщиклопедия» Изд. 2 , перераб, и доп. Главный редактор Ю. Н Караулов. Научное издательство Большая Российская энциклопедия. Изд. Дрофа, Москва, 61-2.

Göncz Lajos 2001. Nyelvi és szociológiai változók összefüggése a Kárpát-medencei magyar beszélőközösségeknél kisebbségi és többségi helyzetben. Magyar Nyelv 97: http://epa. oszk.hu/00000/00032/00009/EPA_00032_magyar_nyelv_2001_02_goncz.htm (Letöltés ideje: 2019. 11. 11.)

Haader Lea 2001. Mikrodiakrónia és változatvizsgálat (az összetett mondatokban). Magyar Nyelvör 125: 354-70.

Hadrovics László 1992. Magyar történeti jelentéstan. Akadémiai Kiadó, Budapest.

Harina, E. Sz. - Харина, Е. С. 2008. Явление симметрии/асимметрии языкового знака. http://pglu.ru/upload/iblock/a20/uch_2008_v_00042.pdf(Letöltés ideje: 2019. 11. 26.)

Harpring, Patricia 2010. Introduction to Controlled Vocabularies: Termiology for Art, Architecture, and Other Cultural Works. Getty Research Institute, Los Angeles.

Hegedüs Irén 2017. Mechanisms of Doublet Formation: Investigating the (mor)phonologylexicology interface in the history of English. University of Pécs Institute of English Studies, Pécs.

Henn-Memmesheimer, Beate 1998. Sprachliche Varianz als Ergebnis von Handlungswahl. Max Niemeyer Verlag, Tübingen. http:/germanistik.unimannheim.de/abteilungen/ germanistische_linguistik/prof_dr_beate_henn_memmesheimer/publikationen_henn memmesheimer/sprachliche_varianz__als_ergebnis_von_handlungswahl/henn_m sprachvarianzhandlungswahl_vorwort1998.pdf (Letöltés ideje: 2019.04 .28 .) https://doi. org/10.1515/9783110918991

Henn-Memmesheimer, Beate 2008. Sprachliche Innovationen als Ready-made. Zur Soziologie und Semantik sprachlicher Varianten. In: Gilles, Peter-Schaloth, Joachim-Ziegler, Evelyn (eds.): Variatio delectat. Empirische Evidenzen und theoretische Passungen sprachlicher Variation. Goethe Universität, Frankfurt, 161-95. http://germanistik.uni-mannheim. de/abteilungen/germanistische__linguistik/prof_dr_beate_henn_memmesheimer/ publikationen henn mem mesheimer/09 henn proofs pdf/09 henn proofs.pdf (Letöltés ideje: 2019.06 .18 .)

Horváth Katalin 2004. Töprengések a szóhasadás jelentőségéről. In: Gecső Tamás (szerk.): Variabilitás és nyelvhasználat. Segédkönyvek a nyelvészet tanulmányozásához XXXIV. Tinta Könyvkiadó, Budapest, 133-42.

Hymes, Dell 1975. A beszélés néprajza. In: Papp Ferenc - Szépe György (szerk.): Társadalom és nyelvhasználat. Akadémiai Kiadó, Budapest, 91-146.

Iturrioz Leza, José Luis - Skopeteas, Stavros 2000. Variation und Invarianz. In: Booij, Geert - Lehmann, Christian - Mugdan, Joachim - Kesselheim, Wolfgang - Skopeteas, Stavros (eds.): Morphologie. Ein internationales Handbuch zur Flexion und Wortbildung. 1. Halbband. Walter de Gruyter, Berlin - New York, 234-47. 
Istók Béla 2019. Netnyelvészeti kaleidoszkóp. Eruditio - Educatio 14: 83-99.

Jarceva, V. N. - Ярцева, В. Н. 1983. Проблема вариативности и взаимоотношение уровней грамматической системы языка // Вопросы языкознания. 1983. № 5. С., 17-24.

Jarošová, Alexandra 2009. Problematika lexikálnej variantnosti a spôsoby jej lexikografického zachytenia. In: Považaj, Matej (ed.): Dynamické tendenciev slovenskom pravopise. Zborník materiálov z vedeckej konferenciekonanej 18. - 19. mája 2006 v Bratislave. VEDA, Bratislava, 98-134.

Kalcsó Gyula 2007. A névszóinflexió nyelvi változói a magyar nyelvü nyomtatott írásbeliség elsö fél századában. PhD-értekezés. ELTE, Budapest. Kézirat.

Karcevski, Sz. O. - Карцевский, С. О. 1929/1965. Об асимметричном дуализме языкового знака. In: В. А. Звегинцев (ред.): История языкознания XIX-XX веков в очерках и извлечениях. 3-е изд. Ч.2. Москва, 85-93.

Kardos Tamás 1992. Az orosz nyelvi normára irányuló újabb kutatások. In: Kemény Gábor (szerk.): Normatudat - Nyelvi norma. Linguistica. Series A. Studia et dissertaciones 8. A Magyar Tudományos Akadémia Nyelvtudományi Intézete, Budapest, 163-74.

Károly Sándor 1970. Általános és magyar jelentéstan. Akadémiai Kiadó, Budapest.

Keszler Borbála 1974. Az igető-váltakozásból eredő párhuzamos alak- és jelentésmegoszlás. In: Imre Samus - Szathmári István (szerk.): Nyelvtudományi Értekezések 83. sz. Akadémiai Kiadó, Budapest, 281-82.

Kiss Jenő 2002. Társadalom és nyelvhasználat. Nemzeti Tankönyvkiadó, Budapest.

Kiss Jenő 2003. Magyar dialektológia. Osiris Kiadó, Budapest.

Kiss Jenő 2008. A nyelvi változás - kutatói dilemmák. Magyar Nyelv 104: 257-74.

Kiss Jenő - Pusztai Ferenc (szerk.) 2003. Magyar nyelvtörténet. Osiris Kiadó, Budapest.

Klein, Wolfgang 1974. Variantengrammatik. Variation in der Sprache. Ein Verfahren zu ihrer Beschreibung. Scriptor Verlag GmbH., Kronberg, 97-106.

Klein, Wolfgang 1976. Sprachliche Variation. Studium Linguistik 1: 29-46.

Klein, Wolf Peter 2003. Sprachliche Zweifelsfälle als linguistischer Gegenstand. Zur Einführung in ein vergessenes Thema der Sprachwissenschaft. Linguistik online 16, 4/03: 5-33. https://www.linguistik-online.net/16_03/klein.pdf (Letöltés ideje: 2019. 10. 21.)

Klein, Wolf Peter 2018. Sprachliche Zweifelsfälle im Deutschen. Theorie, Praxis, Geschichte. Walter de Gruyter, Berlin-Boston. https://doi.org/10.1515/9783110495317

Knipf-Komlósi, Elizabeth - Rada, Roberta V.-Bernáth, Csilla 2006. Aspekte des Wortschatzes. Bölcsész Konzorcium. http://mek.niif.hu/04900/04913/04913.pdf (Letöltés ideje: 2011. 06. 19.)

Labov, William 1982. Building on Empirical Foundations. In: W. P. Lehmann -Y. Malkiel (eds.): Perspectives on Historical Linguistics. John Benjamins, Amsterdam-Philadelphia, 17-92.

Labov, William. 2004. Quantitative reasoning in linguistics. In: Ammon, Ultich - Dittmar, Norbert - Mattheier, Klaus J. - Trudgill, Peter (eds.): Sociolinguistics/Soziolinguistik: an international handbook of the science of language and society. Volume I. Mouton de Gruyter, Berlin - New York, 6-22. http://www.ling.upenn.edu/ wlabov/Papers/QRL.pdf (Letöltés ideje: 2019. 02. 26.)

Laczkó Krisztina 2000. Az alaktan tárgya és alapkategóriái. In: Keszler Borbála (főszerk.): Magyar grammatika. Nemzeti Tankönyvkiadó, Budapest, 37-50.

Ladányi Mária 2004. Rendszer - norma - nyelvhasználat: Igekötős neologizmusok helyi értéke. In: Büky László (szerk.): Nyelvleírás és nyelvmüvelés, nyelvhasználat, stilisztika. A mai magyar nyelv leírásának újabb módszerei VI. Szegedi Tudományegyetem Általános Nyelvészeti Tanszék, Szeged, 96-116.

Lamb, S. M. 1962. Outline of Stratification Grammar. Georgtown University Press, Washington. Oroszul: Очерки стратификационной грамматики. Минск, 1977. 
Langacker, R. W. 1987. Foundations of Cognitive Grammar. Standford University Press. Stanford, California.

Lanstyák István 2006a. Nyelvi változatosság a határon túli magyar szókincsben. Kisebbségkutatás 14/1. https://epa.oszk.hu/00400/00462/00029/cikk8825.html (Letöltés ideje: 2019. december 17.)

Lanstyák István 2006b. A nyelvi változatosság mint szótártani probléma. (Adalékok a határtalanítás módszertanához). In: Lanstyák István (szerk.): Nyelvböl nyelvbe. Tanulmányok a szókölcsönzésről, kódváltásról és fordí-tásról. Kalligram Könyvkiadó, Pozsony, 57-104.

Lanstyák István 2006c. A kölcsönszavak rendszerezéséről. In: Lanstyák István (szerk.): Nyelvböl nyelvbe. Tanulmányok a szókölcsönzésröl, kódváltásról és forditásról. Kalligram Könyvkiadó, Pozsony, 15-56.

Lanstyák István 2009. A magyar beszélt nyelv sajátosságai. Stimul, Pozsony.

Lavandera, Beatriz 1978. Where does the sociolinguistic variable stop? Language in Society 7. http://lingo.stanford.edu/sag/L204/syll/BL/ (Letöltés ideje: 2019. 12. 08.) https://doi. org/10.1017/S0047404500005510

Lehmann, Christian 2009. Sprachtheorie. Universität Erfurt. Philosophische Fakultät. Veranstaltungsskript. http://www.christianlehmann.eu/ling/ling_theo/index.html (Letöltés ideje: 2013. 01. 12.)

Lendvai Endre - Лендваи, Эндре 1998. Лексическая семантика (Lexikai szemantika). Tankönyvkiadó, Budapest.

Lockwood, D. G. 1972. Introduction to stratificational linguistics. Harcourt Brace Jovanovich, New York.

Lőrincz Gábor 2014. A nyelvi variativitás a szlovákiai magyar anyanyelvtankönyvekben. EKF Líceum Kiadó, Eger.

Lőrincz Gábor 2016. Nyelvi variativitás a szlovákiai magyar nyelvváltozatokban. Pandora Könyvek 38. EKE Líceum Kiadó, Eger.

Lőrincz Julianna - Jászay László 2001. Variancia az orosz ige paradigmájában. EKF Líceum Kiadó, Eger.

Lőrincz Julianna 2004a. A funkcióigés szerkezetek és a főnévi taggal azonos tövü igék varianciája. In: Kurtán Zsuzsa - Zimányi Árpád (szerk.): A nyelvek vonzásában. Köszöntő kötet Budai László 70. születésnapjára. Veszprémi Egyetemi Kiadó, Eger-Veszprém, $104-9$.

Lőrincz Julianna 2004b. A magyar igevariánsok grammatikai és pragmatikai jellemzői. VII. Nemzetközi Magyar Nyelvtudományi Kongresszus. Budapest, Kézirat.

Lőrincz Julianna 2009. Nyelvi jelentés és variativitás. Selye János Egyetem, Komárom.

Lőrincz Julianna 2010. A nyelvi variativitás terminológiai kérdései. In: Nagy Melinda (szerk.): Társadalmi jelenségek és változások. II. Nemzetközi Tudományos Konferencia SJE. Selye János Egyetem, Komárom, 678-84.

Lőrincz Julianna 2011. A variánsok helye és funkciója a magyar nyelvben. In: Lőrincz Julianna (szerk.): Kommunikáció - Stílus - Variativitás és anyanyelvoktatás. Pandora Könyvek 24. EKF Líceum Kiadó. Eger. 135-141.

Máté Jakab 1998. Elméletek, irányzatok és módszerek II. A 20. századi nyelvtudomány történetének föbb elméletei és irányzatai. Nemzeti Tankönyvkiadó, Budapest.

McMahon, April M. S. 1994. Understanding Language Change. Cambridge University Press, Cambridge.

[MGr.] = Keszler Borbála (főszerk.) 2000. Magyar grammatika. Nemzeti Tankönyvkiadó, Budapest.

Misad Katalin 2009. Nagybetúsítések a szlovákiai magyar írásgyakorlatban. In: Misad Katalin (szerk.): Nyelvi kontaktusok. Szlovákiai magyar vonatkozású alkalmazott nyelvészeti tanulmányok. Lilium Aurum, Dunaszerdahely, 119-39. 
Misad Katalin 2011. Standardtól eltérő helyesírási formák a szlovákiai magyar nyelvü sajtóban. In: Szabómihály Gizella - Lanstyák István (szerk.): Magyarok Szlovákiában VII. kötet. A nyelv. Fórum Kisebbségkutató Intézet, Somorja, 133-49.

Misadová, Katarína 2011. Kapitoly z morfológie mad'arského jazyka. Kontrastívny opis niektorých morfologických javov mad'arského jazyka. Univerzita Komenského v Bratislave, Bratislava.

Muthmann, Gustav 1994. Doppelformen in Der Deutschen Sprache Der Gegenwart: Studie zu den Varianten in Aussprache, Schreibung, Wortbildung und Flexion. Niemeyer Verlag, Tübingen. https://doi.org/10.1515/9783110958508

Nádasdy Ádám 2003. Miért változik a nyelv?

www.okm.gov.hu > letolt > retorika > szoveg > szov > nadasdy_nyomtathato (Letöltés ideje: 2019. 11. 12.)

[NyKk.] = Grétsy László - Kovalovszky Miklós (föszerk.) 1980. Nyelvmüvelö kézikönyv I-II. Akadémiai Kiadó, Budapest.

Oszetrov, I. G. - Осетров, И. Г. 2009. Симметрия и асимметрия: онтологический и лингвистический аспекты. Вестник МГУ 2: 55-60.

Pete István 2004. Zérók és nem zérók. Kis pro-k és nagy-PRO-k a magyarban. Magyar Nyelvör 128: 326-39.

Péter Mihály 1980. A prágai iskola. In: Balázs János (szerk.): Nyelvi rendszer és nyelvhasználat. Tankönyvkiadó, Budapest, 116-37.

Rozental, D. E. - Tyelenkova, М. А.- Розенталь, Д. Э. - Теленкова, М. А. 1976. Словарьсправочник лингвистических терминов. 2, доп. издание. Изд. «Просвещение», Москва.

Romaine, Suzanne 1995. Internal and external factors in socio-historical explanations of change: a fruitless dichotomy? In: Ahlers, J. et al. (eds.): General Session and Parasession on Historical Issues in Sociolinguistics/Social Issues in Historical Linguistics. Berkeley Linguistics Society: Proceedings of the Annual Meeting 21. Berkeley, CA, 478-90. http:// elanguage.net/journals/bls/article/download/3119/3100 (Letöltés ideje: 2019. 05. 07.) https://doi.org/10.3765/bls.v21i1.1404

Sándor Klára 2001. A nyelv „gyenge pontjai”. In: Károly László - Kincses Nagy Éva (szerk.): Néptörténet - nyelvtörténet. A 70 éves Róna-Tas András köszöntése. SZTE BTK Altajisztikai Tanszék, Szeged, 119-35.

Sinner, Carsten 2014. Varietätenlinguistik. Eine Einführung. Narr Studienbücher. Narr Verlag, Tübingen.

Szabómihály Gizella - Lanstyák István 2011. Nyelviváltozó-típusok a magyar nyelv szlovákiai változataiban. In: Szabómihály Gizella - Lanstyák István (szerk.): Magyarok Szlovákiában VII. kötet. A nyelv. Fórum Kisebbségkutató Intézet, Somorja, 113-25.

Szathmári István 1999. A funkcionális stilisztika és a szótőváltozatok. In: Kugler Nóra - Lengyel Klára (szerk.): Ember és nyelv. Tanulmánykötet Keszler Borbála tiszteletére. ELTE Mai Magyar Nyelvi Tanszék, Budapest, 301-4.

Szolncev, V. G. 1984. Солнцев, В. М. Вариативность как общее свойство языковой системы // Вопросы языкознания. № 2. С. 31-42.

Szolncev, V. G. 1997. - Солнцев, В. М. Вариантность, вариативность (Variálhatóság, variativitás). In: Русский язык - энииклопедия. Главный редактор Ю. Н. Караулов, изд. 2-е, перераб. и доп. «Большая Российская энциклопедия». Издательский дом «Дрофа». Москва. 60.

Tolcsvai Nagy Gábor 1998. A nyelvi norma. Nyelvtudományi Értekezések 144. Akadémiai Kiadó, Budapest. 
Tolcsvai Nagy Gábor 2004. A nyelvi variancia kognitív leírása és a stílus (Egy kognitív stíluselmélet vázlata). In: Büky László (szerk.): A mai magyar nyelv leírásának újabb módszerei VI. SZTE Általános Nyelvészeti Tanszék, Magyar Nyelvészeti Tanszék, Szeged, 143-60.

Tóth Etelka 2002. Napjaink irodalmi és köznyelvének kettős alakjai. PhD-értekezés. ELTE, Budapest, Kézirat.

Tóth, Sándor János 2017. Aspekty slovensko-mad'arskej porovnávacej morfosyntaxe. Monographiae Comaromienses 19. Univerzita J. Selyeho, Komárno.

Török Tamás 2010. Külterületi helynevek fordíthatósága: Alsó-Ipoly mente és Zoboralja magyar dűlőneveinek szlovák változatairól. In: Lendvai Endre - Wolosz Robert (szerk.): TRANSLATOLOGIA PANNONICA III. Kultúrák dialógusa a soknyelvü Európában VII. konferencia tanulmánykötete. PTE BTK FKK, Pécs, 65-74.

Török Tamás 2012. Helynevek és fordítástudomány: A mikrotoponimák fordíthatóságáról felvidéki példák alapján. In: Hoffmann István - Tóth Valéria (szerk.): Helynévtörténeti Tanulmányok 7. Debreceni Egyetemi Kiadó,. Debrecen,. 117-32.

Török Tamás 2013. Hungarian Place Names - Slovak Maps.: Hungarian Place Names on Slovak Maps of the Areas Around Zobor and the Lower Areas of the River Ipoly. Eruditio - Educatio 8/3: 71-89.

Trudgill, Peter 1992. Bevezetés a nyelv és társadalom tanulmányozásába (ford. Sándor Klára 1997). JGYTF Kiadó, Szeged.

Wardhaugh, Ronald 2002. Szociolingvisztika. Osiris Kiadó, Budapest.

Wolfram, Walt 2006. Variation and Language, an Overview. In: Brown, K. (ed.): Encyclopedia of Language and Linguistics, 2nd edition. Elsevier, Oxford. https://pdfs.semanticscholar.o rg/5f57/244767a6a20b4785d0003bb7a93e4eab959b.pdf (Letöltés ideje: 2018. 05. 17.)

$\mathrm{W} 1$ = http://mediawiki.ids-mannheim.de/VarGra/index.php/Start (Letöltés ideje: 2020. 01. 02.)

Zsemlyei János 2002/2009. A mai magyar nyelv szókészlete. III. rész. (részletek a szerző 2002-ben megjelent A mai magyar nyelv szókészlete és szótárai címủ egyetemi jegyzetéből). Erdélyi Tankönyvtanács, Kolozsvár. http://www.nyeomszsz.org/orszavak/pdf/ ZSEMLYEI3Teljes.pdf (Letöltés ideje: 2011. 08. 15.)

\author{
Lörincz Gábor \\ egyetemi adjunktus \\ Selye János Egyetem TKK \\ Magyar Nyelv és Irodalom Tanszék \\ https://orcid.org/0000-0001-7543-7758 \\ Lörincz Julianna \\ habil. egyetemi docens \\ Selye János Egyetem TKK \\ Magyar Nyelv és Irodalom Tanszék \\ https://orcid.org/ 0000-0002-1748-7033
}

\title{
SUMMARY
}

$$
\text { Lörincz, Gábor-Lörincz, Julianna }
$$

\section{Theoretical questions of language variativity}

In this paper we deal with a number of theoretical questions of language variativity. Variativity shows the existence and functioning of variants that occur together in language use. Variants are defined as instances of linguistic variation that are similar in form, equivalent in denotative, lexical and grammatical meanings, but whose pragmatic meanings are different, so they are used in different real-life situations of communication. 
Our starting point was the phenomena of symmetry and asymmetry in connection with language change. We intended to clarify the differences between variativity and variability, and the relationship between variativity and language norm. Then we discussed the place of variant forms among language variables and the connection between variants and the invariant. Finally, we reviewed the types of variants at diverse levels of language based on the Hungarian and international literature.

We are interested in this area because it is known by Hungarian and foreign linguists even if in the published literature it is analyzed from the aspect of sociolinguistics and not from a prescriptive viewpoint. Therefore, linguists tend to use different terminology in dealing with variativity, and that is the reason why there is overlapping and ambiguity between variativity and similar lexico-semantic relationships (synonymy, polysemy, paronymy) as well as other linguistic phenomena (word split, doublets, convergent development of form and meaning).

Keywords: symmetry/asymmetry, language variability, language variativity, language change, language norm, invariant.

\section{Miskóltzy Ferentz orvosi szavai}

\section{Bevezetés}

Miskóltzy Ferentz sebész, orvos, tanácsos életéről (akit a nyelvújítás előhírnökének tekinthetünk) keveset tudunk. Többnyire azt olvashatjuk, hogy 1697. febr. 21.-1771. okt. 30-ig élt. Az biztos, hogy 1730 körül vette feleségül Murai Katalint, és ekkor telepedett le Győrben. 1733-tól több gyermeke is született. Mint sebész kezdte meg a tevékenységét (egyes források szerint céhmester volt). 1734-ben megválasztották városi kapitánynak. 1748-tól Győr város orvosa lett. Petz Aladár (1929: 24) Mayer Ferencre hivatkozva megírja, hogy 1748-ban az oklevelek tanúsága szerint Miskóltzy részt vett a Szentháromság kórház alapkőletételénél, és hogy később a kórházban dolgozott. Az utóbbit az bizonyítja, hogy 1761-ben Miskóltzy Ferentz sebész-céhmester, chirurgus nevével egy nőbeteg lábtörésével kapcsolatosan lehet találkozni a számadásokban, és innen megtudjuk azt is, hogy évi salaruma 8 forint volt, valamint azt is, hogy 1762-től utódja Bander Simon lett (i. m. 58). Azt, hogy orvosként emlegetik, talán azzal lehet magyarázni, hogy nagyon kevés orvosdoktor volt Magyarországon, ezért néhány megye kénytelen volt chyrurgusokat alkalmazni physicusként. Bács vármegye például 1762-ben nem talált olyan orvost, aki évi 600 Ft-ért elvállalta volna a megyei physicus szerepét. Aki számításba jöhetett volna, azt a győri püspök fogadta szolgálatába. A súlyos járványok miatt azonban kénytelenek voltak felvenni föorvosnak egy sebészt (Simon Katalin 2011: 59). Az 1760-as évektöl már általánossá vált, hogy bizonyos sebészeket foglalkoztattak városonként, megyénként évi juttatás fejében orvosnak (i. h.). Miskóltzyt 17601771-ig városi tanácsosnak is megválasztották (Kapronczay 2004: 1085; Csillag István 1962: 1083) 